\title{
Tvö sjúkratilfelli: Ormur í auga og endurteknar bólgur á útlimum
}

\section{Davíd Pór Bragason ${ }^{1}$ \\ María Soffía Gottfreðsdóttir ${ }^{1}$ \\ Birgir Jóhannsson² \\ Magnús Gottfreðsson ${ }^{2,3}$}

Höfundarnir eru öll læknar.

Augndeild ${ }^{1}$, smitsjúkdómadeild Landspítala² ${ }^{2}$ læknadeild Háskóla Íslands. ${ }^{3}$

Fyrirspurnum svarar Magnús Gottfreðsson, magnusgo@landspitali.is

\section{Tilfelli 1}

35 ára gömul kona frá Afríku leitaði til augnlæknis vegna ópæginda í auga. Hún hafði búið hér á landi i 6 ár, en hafði heimsótt fæðingarland sitt hálfu ári áður og dvalist par í tvo mánuði. Að morgni komudags tók hún eftir pví að eitthvað virtist hreyfast í hægra auganu. Um var að ræða fyrirbæri sem hreyfðist eftir yfirborði augans og sást með berum augum. Augnlæknirinn staðfesti kvörtun konunnar og sendi hana á augndeild, par sem strax var leitað ráða hjá smitsjúkdómalækni.

Undanfarin 5 til 6 ár hafði konan fundið fyrir prota, útbrotum og kláða á útlimum, oft nálægt hnjám og úlnliðum. Pessi einkenni voru lotubundin, stóðu oftast yfir í fáeina daga en gengu síðan smám saman til baka. Konan hafði um árabil leitað til fjölmargra lækna vegna pessa án pess að skýring fengist, en hafði meðal annars verið sett á barkstera og andhistamín með takmörkuðum árangri.

Konan var heilsuhraust að öðru leyti, en hún starfaði sem skólaliði og átti eitt heilbrigt barn.

Við skoðun varð ljóst að um lifandi orm var að ræða og náðist myndupptaka af honum á síma (myndband og mynd 1). Stærð ormsins var áætluð um $3 \mathrm{~cm}$ á lengd og 0,5 mm í pvermál út frá myndupptökunni. Augnskoðun var að öðru leyti eðlileg fyrir utan vægan roða í augnslímhúð. Konan var án tafar tekin inn á skurðstofu par sem átti að fjarlægja orminn úr auganu, en pó náðist hann ekki prátt fyrir að slímhúðin væri opnuð og vandlega leitað. Pví var pess í stað tekið vefjasýni frá slímhúðinni og sent í vefjarannsókn, ásamt pví að teknar voru blóðprufur sem sýndu væga aukningu á rauðkyrningum (eosinophilia; 0,6 x 109/L) og IgE mótefnum, 188 einingar/mL (<148 einingar/mL). Blóð sem tekið var í tvígang og litað með Giemsa-litun eftir péttingu sýndi engin sníkjudýr. Pess var gætt að blóðtaka færi fram um hádegisbil til að hámarka líkur á að forlirfur (microfilariae) greindust, væru pær til staðar. Engin sníkjudýr greindust heldur í pvagi með sömu aðferð.

\begin{abstract}
Á G R I P
Lýst er tveimur tilfellum af lóasýki hjá konum búsettum hér á landi, 35 ára konu sem fæddist í Afríku og 31 árs konu sem hafði ferðast um Afríku. Pær leituðu til læknis vegna ópæginda frá auga. Við skoðun sást í báđum tilfellum ormur, um $3 \mathrm{~cm}$ á lengd og $0,5 \mathrm{~mm}$ á breidd, sem hreyfðist undir slímhúð augans. Báđar konurnar höfðu einnig einkenni frá útlimum: endurteknar lotubundnar bólgur og kláđa, og vöđvaverki. Greiningin var í báđum tilfellum lóasýki með Calabar-bólgum á útlimum og meðferð með albendazóli og díetýlcarbamazíni leiddi til lækningar. Aukinnar árvekni er pörf gagnvart sýkingum sem hafa verið sjaldgæfar í okkar heimshluta hingaơ til.
\end{abstract}

doi.org/10.17992/lbl.2018.09.197

Niðurstöður mótefnamælinga fyrir Filarioidea (yfirætt práðorma) sem framkvæmdar voru á Statens Serum Institut í Kaupmannahöfn reyndust jákvæðar, en ónæmisglóbúlín G4 (IgG4) mæling, sértæk fyrir Loa loa, var neikvæð.

\section{Tilfelli 2}

31 árs gömul íslensk kona, sem ári fyrr hafði ferðast um Afríku í fjóra mánuði, var send á augndeild vegna gruns um orm undir slímhúð hægra auga. Í Afríku hafði hún sýkst af hornhimnubólgu af völdum svepps (Aspergillus flavus) í vinstra auga og einnig af malaríu og hafði fengið viðeigandi meðferð við pví. Auk pess hafði hún af og til haft vöðvaverki í læri og framhandlegg. Við skoðun sást ormurinn á mynd 2 spriklandi undir slímhúð augans. Að öðru leyti var augnskoðun án athugasemda. Í ljósi reynslunnar af tilfelli 1 , par sem ormurinn náðist ekki vegna pess hve fljótur hann var að koma sér undan, var op klippt án tafar í slímhúðina og náðist ormurinn lifandi. Hann var sendur á sýkla- og veirufræðideild par sem hann var greindur sem fullorðinn Loa loa ormur. Blóðrannsókn sýndi hækkun á rauðkyrningum $\left(2,7 \times 10^{9} / \mathrm{L}\right)$ og sermispróf fyrir Trichinella spiralis (purkormi) var jákvætt. Sermispróf fyrir Schistosoma (blóðögðuveiki) og Toxocara (spóluormi) voru neikvæð, en sermispróf fyrir práðorminum Strongyloides stercoralis var á mörkum. Í endurteknum blóð-, hægða- og pvagsýnum fundust ekki forlirfur práðorma.

\section{Meðferð og afdrif}

Að rannsókn og aðgerð lokinni voru sjúklingarnir meðhöndlaðir með sýkladrepandi og bólgueyðandi augndropum (dexametasón, 


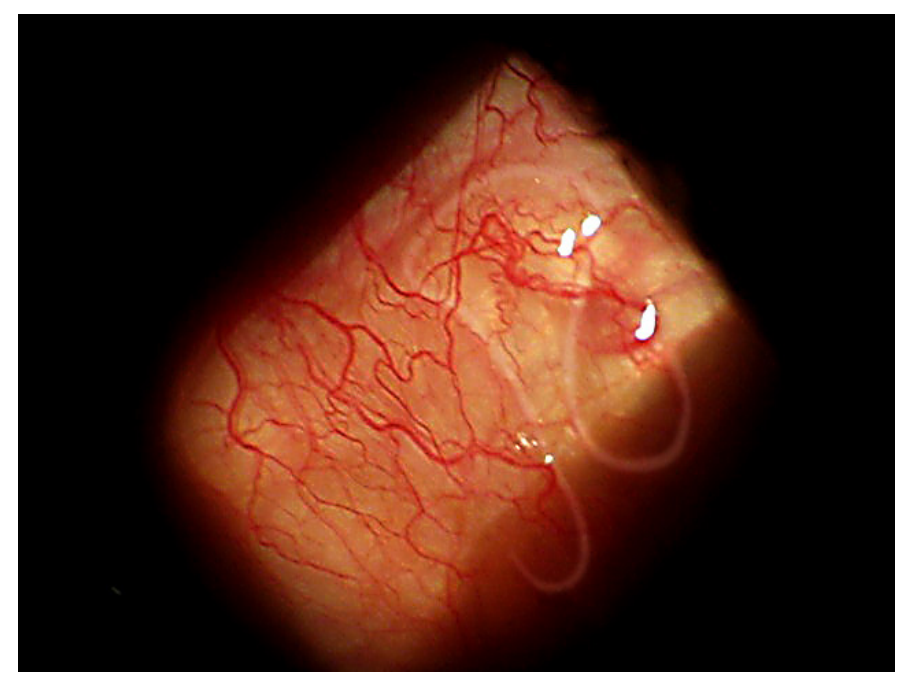

Mynd 1. Loa loa ormur undir slímhúd auga 35 ára konu. Mynd skerpt. Lengd orms um $3 \mathrm{~cm}$.

oxýtetrasýklín og pólímyxín í tilfelli 1 og levófloxasín í tilfelli 2) og varð hvorug aftur vör við orm í auganu. Klínískt var talið ljóst að um lóasýkingu (Loa loa) væri að ræða og fékkst pað staðfest í tilfelli 2 með tegundargreiningu á orminum á sýkladeild. Var meðferð ráðgerð í samræmi við pað, en lyfin purfti að sérpanta erlendis frá. Í tilfelli 1 var meðhöndlað með albendazóli 200 mg tvisvar á dag í prjár vikur og síðan með díetýlkarbamazíni (DEC) í vaxandi skömmtum, 1-10 mg/kg/dag í prjár vikur. Í tilfelli 2 var meðhöndlað með albendazóli einu sér í sama skammti í prjár vikur, en pað lyf er einnig virkt gegn Trichinella práðormi, sem grunur var um að væri einnig til staðar, samanber sermispróf.

Í tilfelli 1 gerðu einkenni ekki vart við sig eftir að meðferð lauk. Við eftirlit tveimur vikum eftir upphaf meðferðar sagði konan að sér hefði sjaldan liðið betur, pví að húðútbrot, bólgur og kláði á útlimum voru horfin.

Í tilfelli 2 hafði konan verið einkennalaus í 7 mánuði eftir lok meðferðar, pegar hún hafði aftur samband vegna gruns um lifandi orm undir húð á handlegg. Pá var enn til staðar hækkun á rauðkyrningum í blóði og fékk konan pá aftur meðferð með albendazóli 200 mg tvisvar á dag í prjár vikur. Skömmu síðar flutti hún af landi brott par sem hún greindist rúmu ári síðar með sýkingu af völdum práðormsins Strongyloides stercoralis. Eftir meðferð með ivermectin gengu einkenni, sem og hækkun á rauðkyrningum í blóði og IgE, til baka.

\section{Umræða}

Hér er lýst fyrstu tveimur tilfellum af lóasýki, eða afrískum augnormi, sem okkur er kunnugt um á Íslandi. Með vaxandi fjölda innflytjenda og innlendra og erlendra ferðamanna frá fjarlægum slóðum er viðbúið að framandi sýkingar taki að reka á fjörur íslenskra lækna. Lóasníkillinn Loa loa er práđormur sem berst í menn með biti dádýraflugu (Chrysops spp., mynd 3) og er landlægur víða í Vestur- og Mið-Afríku. Talið er að 10 milljónir manna séu sýktar, en 30 milljónir eru útsettar fyrir sníklinum og vangreining algeng. ${ }^{1,2}$ Á vissum svæðum Afríku er algengi sýkingarinnar meðal íbúa meira en $40 \% .^{2}$ Ferðamenn geta sýkst, en hættan er fremur lítil par sem að sýkingarhættan er tengd pví hversu lengi fólk er útsett. $^{3}$

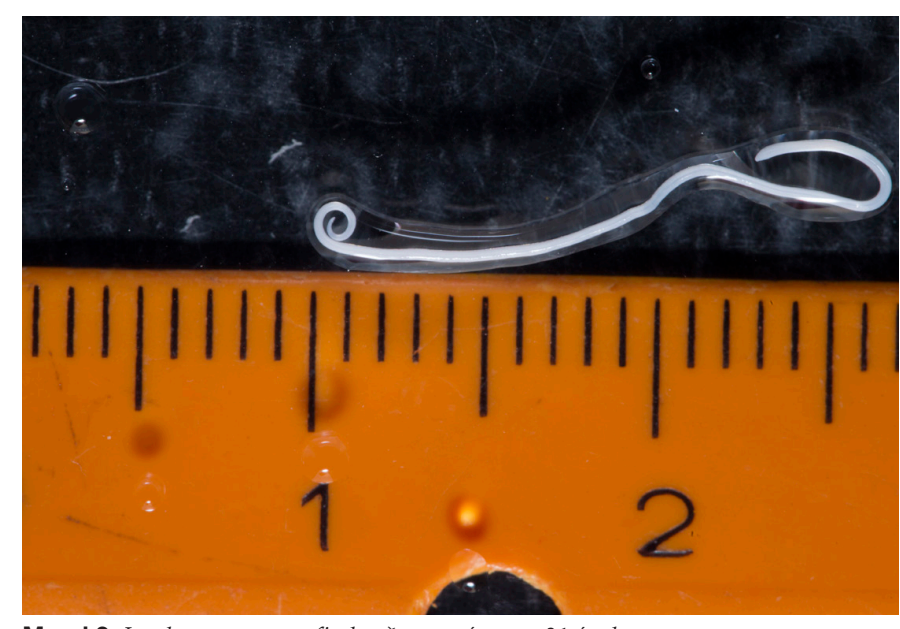

Mynd 2. Loa loa ormur sem fjarlægður var úr auga 31 árs konu.

L. loa smitast pegar dádýraflugur bíta fólk til blóðs, en við pað berast lirfur práđorma á priðja proskastigi (third stage filarial larvae) í bitsárið. Pessar lirfur proskast síðan í fullorðna orma á premur mánuðum. Fullvaxta ormar geta valdið sýkingareinkennum; peir halda gjarnan til í undirhúð en geta ferðast um allan líkamann, par með talið til augna. Eftir 6-12 mánuði taka hinir fullorðnu ormar að fjölga sér og geta losað mörg púsund forlirfur (microfilariae) í blóðrásina og við pessar aðstæður er stundum unnt að greina sýkinguna í blóðstroki, sem er mikilvæg greiningaraðferð. Forlirfur halda mest til í lungum, en fara reglulega út í blóðrásina, mest um hádegisbil. Pví er mikilvægt að blóðtaka fari fram á peim tíma ef greina á forlirfur í blóðstroki. Forlirfur eru síðan teknar upp af flugum er pær bíta sýkta einstaklinga, en par dveljast forlirfur í 10-12 daga uns pær mynda priðja stigs práðormalirfur; pannig er hringrás sýkingarinnar viðhaldið. Fullorðnir ormar í mönnum geta náð 20 ára aldri. ${ }^{4}$ Algengt er að fullvaxta kvenormur sé $5-7 \mathrm{~cm}$ á lengd og 0,3-0,5 mm á breidd, en karlormar eru að jafnaði helmingi minni. Dæmigerðan fullorðinn orm má sjá á mynd 2. Flestir hinna sýktu eru einkennalausir, en aðaleinkenni lóasýkingar eru tvenns konar og voru sjúklingarnir sem hér er lýst með pau bæði, annars vegar lotubundnar bólgur í undirhúð sem nefnast Calabar-bólgur (nefndar eftir borg í Nígeríu), hins vegar ormar sem hreyfast eftir yfirborði augans og valda hugarvíli, ópægindum og bólgusvörun.

Pegar einstaklingar sem ekki hafa áður myndað mótefni smitast á ferðalagi um svæði par sem sýkingin er landlæg, geta peir fengið ofnæmiseinkenni, svo sem ofsakláða (urticaria), Calabar-bólgur og jafnvel astma. ${ }^{5,6}$ Pessi einkenni geta varað árum saman eftir að svæðið hefur verið yfirgefið, enda geta fullorðnir ormar verið langlífir eins og áður er getið. Calabar-bólgur stafa af ofsabjúg (angioedema) sem talinn er stafa af ofnæmisviðbrögðum sem ormurinn kallar fram á ferðalagi sínu um líkamann. •ær geta komið fram hvar sem er, en algengast er að pær komi fram á útlimum eða andliti, oft í kjölfar fyrirboða sem er ýmist kláði eða verkur á svæðinu. Bólgurnar eru oftast roðalausar, pær geta prýst á nálægar taugar og liði og standa gjarnan yfir í tvo til fjóra daga, stundum lengur. Ormarnir eru stundum kyrrir um hríð, en geta síðan hreyfst allhratt, meira en $1 \mathrm{~cm}$ á mínútu, eins og sjá má í myndbandi 1. Augneinkenni ganga til baka án fylgikvilla í 


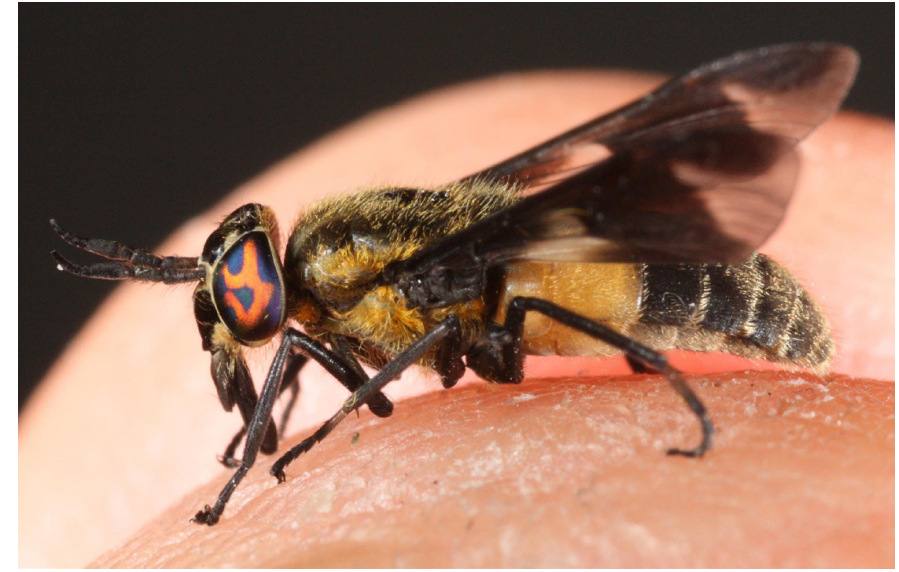

Mynd 3. Dádýrafluga (Chrysops spp.), smitberi lóasýki. Mynd af Wikipedia.

langflestum tilvikum og afar sjaldgæft er að ormurinn leiti inn í augnknöttinn.?

Aðrir sjaldgæfari fylgikvillar lóasýkingar eru meðal annars heilabólga, hjartavöðvakvilli og nýrnasjúkdómur með blóðog prótínmigu. Flestir eru með hækkaða rauðkyrninga í blóði (eosinophilia) en einnig er algengt að hækkun mælist á heildarmótefnum og IgE. Greiningin er pó fyrst og fremst klínísk og byggir á að sjá og greina orminn, enda pótt fleiri atriði, svo sem nákvæm sögutaka, skoðun á blóðstroki par sem stundum sjást forlirfur, og almennar blóðrannsóknir gegni einnig mikilvægu hlutverki.

Vert er að hafa í huga að fleiri práðormar geta valdið augnsýkingum, svo sem Onchocerca volvulus sem veldur árblindu (river blindness; onchocerciasis), Wuchereria bancrofti og Mansonella perstans, en útlit pessara sníkla og líffræðileg hegðun er mismunandi.

Mikilvægt er að rugla ekki saman augneinkennum árblindu og lóasýki, par sem árblinda er ein helsta orsök blindu af völdum smitsjúkdóms í heiminum, en lóasýki veldur ekki sjónskerðingu. Enn fremur er mikilvægt að greina samsýkingu (co-infection) af lóasýki og árblindu, par sem pað skiptir miklu máli við val á meðferð. Blóðvatnspróf geta komið að góðum notum, einkum meðal ferðamanna og peirra sem eru brottfluttir af svæðum par sem sýkingin er landlæg. Notagildið er hins vegar takmarkað meðal íbúa par sem sýkingin er landlæg enda eru margir með mótefni og pau eru lengi greinanleg eftir lækningu. Nýrri aðferðir sem mæla IgG4 mótefni eru taldar vera sértækari (98\%), en næmi aðferðarinnar er aðeins $56 \%^{8}$ eins og sást í okkar sjúklingi sem var með neikvæða niðurstöðu prátt fyrir að ormurinn væri sjáanlegur.

Unnið er að próun fleiri greiningarprófa, meðal annars sjálfvirks sníklateljara (LoaScope) sem byggir á smásjárskoðun blóðs og tengist við snjallsíma til að greina sjúklinga hvar sem er utan heilbrigðisstofnana. ${ }^{9}$ Helsta notagildi sníklateljarans felst pó ekki í greiningu á lóasýki sem slíkri, heldur í að greina pá sem hafa mikið magn L. loa forlirfa í blóði, en peir einstaklingar eru í hættu á að fá alvarlegar aukaverkanir ivermectin meðferðar pegar stórir hópar fólks eru meðhöndlaðir á svæðum par sem árblinda (onchocerciasis) eða fílaveiki (lymphatic filariasis, elephantiasis) er landlæg (mass drug administration).

Kjörmeðferð við lóasýkingu er DEC, sem hefur góða virkni gegn práðorminum á mismunandi proskastigum, forlirfum sem fullorðnum ormum. Ef sníklafjöldi í blóði er hár geta aukaverkanir komið fram af meðferðinni og er pví mælt með blóðstroki ásamt sníklatalningu áður en meðferð hefst. Ef sníklafjöldinn er mikill eða ópekktur, er mælt með að gefa fyrst meðferð með albendazóli í prjár vikur eins og gert var í tilfelli $1 .^{10}$ Sá annmarki er pó á meðferðinni að albendazól hefur minni virkni en DEC, pað drepur aðeins fullorðna orma, en hefur minni aukaverkanir. ${ }^{1}$ Hugsanlegt er að endurkoma einkenna í tilfelli 2 skýrist af pví að albendazól hefur takmarkaða virkni gegn forlirfur (microfilariae) $L$. loa. Oftast er ekki fýsilegt að fjarlægja orminn vegna pess hversu hreyfanlegur hann er, en með pví móti fæst pó nákvæm greining.

Forvarnir gegn lóasníklinum beinast fyrst og fremst að pví að forðast flugnabit. Ekkert bóluefni er til, en talið er að mikil notkun á ivermektíni til að útrýma árblindu hafi átt sinn pátt í að draga úr útbreiðslu sýkingarinnar. ${ }^{1}$ Einnig má íhuga lyfjagjöf með DEC, 300 mg vikulega, ef til dæmis er um að ræða Vesturlandabúa sem starfa tímabundið á svæðum par sem sýkingin er útbreidd.

Lóasýking er ekki talin til vanræktra hitabeltissjúkdóma af Alpjóðaheilbrigðisstofnuninni, ${ }_{11}^{11}$ en nýlegar rannsóknir benda pó til að sýkingunni fylgi aukin dánartíðni ${ }^{12}$ og lagt hefur verið til að sjúkdómurinn verði talinn til pessara sjúkdóma. ${ }^{1}$ Með auknum ferðalögum má gera ráð fyrir að sýkingar af ýmsum toga sem fæstir íslenskir læknar pekkja nema af afspurn muni í vaxandi mæli koma til peirra kasta. ${ }^{13}$ Vert er að hafa slíka sjúkdóma í huga hjá sjúklingum með ódæmigerð og prálát einkenni eins og í fyrra tilfelli okkar.

\section{Heimildir}

1. Metzger WG, Mordmuller B. Loa loa-does it deserve to be neglected? Lancet Infect Dis 2014; 14: 353-7.

2. Zouré HG, Wanji S, Noma M, Amazigo UV, Diggle PJ Tekle AH, et al. The geographic distribution of Loa loa in Africa: results of large-scale implementation of the Rapid Assessment Procedure for Loiasis (RAPLOA). PLoS Negl Trop Dis 2011; 5: e1210.

3. Rakita RM, White AC Jr, Kielhofner MA. Loa loa infection as a cause of migratory angioedema: report of three cases from the Texas Medical Center. Clin Infect Dis 1993; 17: 691-4.

4. Richardson ET, Luo R, Fink DL, Nutman TB, Geisse JK, Barry M. Transient Facial Swellings in a Patient With a Remote African Travel History. J Travel Med. 2012; 19: 183-5.
5. Klion AD, Massougbodji A Sadeler BC, Ottesen EA Nutman TB. Loiasis in endemic and nonendemic populations: immunologically mediated differences in clinical presentation. J Infect Dis. 1991; 163: 1318.

6. Gobbi F, Postiglione C, Angheben A, Marocco S, Monteiro G, Buonfrate D, et al. Imported loiasis in Italy: an analysis of 100 cases. Travel Med Infect Dis 2014; 12: 713-7.

7. Beaver PC. Intraocular filariasis: a brief review. Am J Trop Med Hyg 1989; 40: 40-5.

8. Klion AD, Vijaykumar A, Oei T, Martin B, Nutman TB Serum immunoglobulin G4 antibodies to the recombinant antigen, Ll-SXP-1, are highly specific for Loa loa infection. J Infect Dis 2003; 187: 128-33.
9. Kamgno $\mathrm{J}$ Pion $\mathrm{SD}$, Chesnais $\mathrm{CB}$, Bakalar $\mathrm{MH}$ D'Ambrosio MV, Mackenzie CD, et al. A Test-and-NotTreat Strategy for Onchocerciasis in Loa loa-Endemic Areas. N Engl J Med. 2017; 377: 2044-52.

10. Klion AD, Massougbodji A, Horton J, Ekoué S, Lanmasso $\mathrm{T}$, Ahouissou, NL et al. Albendazole in human loiasis: results of a double-blind, placebo-controlled trial. J Infect Dis. 1993; 168: 202-6.

11. Alpjóðaheilbrigðismálastofnunin. who.int/neglected diseases/diseases/en/ - mars 2018.

12. Chesnais CB, Takougang I, Paguélé M, Pion SD, Boussinesq M. Excess mortality associated with loiasis: a retrospective population-based cohort study. Lancet Infect Dis. 2017; 17: 108-16.

13. Rögnvaldsson KG, Guðmundsson S, Gottfreðsson M. Malaría á Íslandi, sjaldgæf en stöđug ógn við ferðalanga. Læknablaðið 2016; 102: 271-6. 


\section{ENGLISH SUMMARY}

\section{Case report: Two patients with eye worm and recurrent swelling of the extremities}

\section{Davíd Pór Bragason ${ }^{1}$ \\ María Soffía Gottfreðsdóttir ${ }^{1}$ \\ Birgir Jóhannsson² \\ Magnús Gottfreðsson ${ }^{2,3}$}

We report two cases of Loa loa (eye worm) infection in Iceland; the former in a 35-year-old woman born in Africa but living in Iceland for several years; the latter in a 31-yearold woman who had traveled in Africa. Both women sought medical attention due to discomfort in one eye. On examination a worm was noted in both cases, moving under the conjunctiva, $3 \mathrm{~cm}$ in length and $0.5 \mathrm{~mm}$ in diameter. Both patients also had symptoms from the extremities; episodic swelling and itching in the former case, and muscle pain in the latter. Both patients were diagnosed with loiasis with Calabar swellings of the extremities and were successfully treated with albendazole and diethylcarbamazine. Increased awareness is needed for infections which previously have been rare in the Nordics.

${ }^{1}$ Department of ophthalmology, ${ }^{2}$ Department of infectious diseases, Landspitali University Hospital, ${ }^{3}$ Faculty of Medicine, School of Health Sciences, University of Iceland.

Key words: loiasis, Loa loa, eye worm, Calabar swellings, microfilariasis.

Correspondence: Magnús Gottfreðsson, magnusgo@landspitali.is 